\title{
REFLEKSI KETERAMPILAN DASAR MENGAJAR MAHASISWA PRAKTIK PENGALAMAN LAPANGAN IAIN PADANGSIDIMPUAN
}

\author{
Yuhanni $^{1}$, Ahmad Nizar Rangkuti ${ }^{2}$ \\ ${ }^{1}$ Madrasah Aliyah Negeri 2 Padangsidimpuan, ${ }^{2}$ Fakultas Tarbiyah dan Ilmu Keguruan \\ Institut Agama Islam Negeri Padangsidimpuan \\ email: nizarahmad1304@yahoo.com
}

\begin{abstract}
The purpose of this study was the determine the perceptions of tutor teacher on the teaching skills of student of the Field Exsperience Practices of the Fakulty of Tarbiyah and Teacher Treaning of IAIN Padangsidimpuan in MAN Padangsidimpuan City. This type of research is descriptive qualitative. The data collection instrument used were observation, interviews and documentations. The data sources needed were all civil service teachers and vice principals for the curriculum section. The result of the study stated that the guidance teachers on the Teaching Skills of students in the Field Experience Practices of the Faculty of Tarbiyah and Teacher Training at IAIN Padangsidimpuan in MAN 2 Padangsidimpuan has ben implemented. But there still neds to be an increase in each component of teaching skills such as skills to open and close lessons, skills to explain questioning skills, skills to provide a variety of skills to provide reinforcement, classroom management skills small group and individual teaching skills, and small group discussion leading skills. So that every teaching skills can be mastered properly by every student to PPL as a professional teacher candidate.
\end{abstract}

Keyword: tutor teacher; teaching skills; practical field experience.

\begin{abstract}
Abstrak
Tujuan penelitian ini adalah untuk mengetahui bagaimana keterampilan mengajar mahasiswa Praktik Pengalaman Lapangan Fakultas Tarbiyah dan Ilmu Keguruan IAIN Padangsidimpuan di MAN 2 Padangsidimpuan. Jenis penelitian ini adalah kualitatif deskriptif. Instrumen pengumpulan data yang digunakan adalah observasi, wawancara dan dokumentasi. Sumber data yang dibutuhkan yaitu seluruh guru pamong dan wakil kepala sekolah bagian kurikulum. Hasil penelitian menyatakan bahwa Keterampilan Mengajar Mahasiswa Praktik Pengalaman Lapangan Fakultas Tarbiyah dan Ilmu Keguruan IAIN Padangsidimpuan di MAN 2 Padangsidimpuan sudah terlaksana dengan baik. Namun, masih perlu adanya peningkatan dari setiap komponen keterampilan mengajar, seperti keterampilan membuka dan menutup pelajaran, keterampilan menjelaskan, keterampilan bertanya, keterampilan mengadakan variasi, keterampilan memberikan penguatan, keterampilan mengelola kelas, keterampilan mengajar kelompok kecil dan perseorangan, dan keterampilan memimpin diskusi kelompok kecil. Agar setiap keterampilan mengajar dapat dikuasai dengan baik oleh setiap mahasiswa PPL sebagai calon guru yang profesional.
\end{abstract}

Kata Kunci: guru pamong; keterampilan mengajar; praktik pengalaman lapangan.

\section{PENDAHULUAN}

Masalah pendidikan selalu menjadi topik perbincangan yang menarik bagi orang tua, guru dan bagi para pakar pendidikan. Masalah pendidikan menjadi perbincangan di berbagai kalangan karena setiap orang menginginkan pendidikan yang berkualitas 
(Hasratuddin, 2015:1). Agar kualitas pendidikan dapat menjadi baik, maka proses pendidikan harus dibenahi dengan sebaik-baiknya. Proses pendidikan merupakan suatu sistem yang dimana terdiri dari input, proses dan output. Input merupakan peserta didik yang akan melaksanakan aktivitas belajar. Proses merupakan suatu kegiatan dari belajar mengajar sedangkan output merupakan hasil dari proses yang telah dilaksanakan. Dari pelaksanaan proses pendidikan tersebut diharapkan dapat menghasilkan Sumber Daya Manusia (SDM) yang berkualitas dan berdaya saing yang tinggi untuk menghadapi persaingan di era globalisasi ini.

Salah satu tujuan Nasional Bangsa Indonesia yang tercantum dalam UndangUndang Dasar 1945 adalah mencerdasakan kehidupan bangsa. Untuk itu perlu adanya peran aktif dari seluruh komponen bangsa agar tujuan tersebut dapat tercapai. Dalam dunia pendidikan, salah satu Sumber Daya Manusia (SDM) adalah guru atau tenaga pendidik. Sebagai tenaga pendidik dunia pendidikan tentunya sangat membutuhkan calon guru yang produktif, berkualitas, dan profesional. Untuk mewujudkan tujuan tersebut calon guru diharuskan memiliki pengetahuan dan keterampilan dalam mengajar.

Dalam upaya mewujudkan tujuan tersebut, tentu lembaga pendidikan harus mampu mengambil langkah antisipatif agar dapat berperan dalam pembangunan sektor pendidikan. Sekolah merupakan salah satu lembaga pendidikan yang di dalamnya terdapat peserta didik dan guru. Dalam mencerdasakan peserta didik, guru mempunyai peranan yang sangat penting.

Salah satu pelaku utama terpenting dalam proses pendidikan adalah guru (Rangkuti \& Jusrina, 2017:118). Guru adalah salah satu penentu proses peningkatan kecerdasan suatu bangsa (Nur Asia, 2019:253). Guru adalah pendidik profesional dengan tugas utamanya adalah mendidik, mengajar, membimbing, mengarahkan, melatih, menilai dan mengevaluasi peserta didik pada jenjang pendidikan anak usia dini jalur pendidikan formal, pendidikan dasar dan pendidikan menengah (Kamil dkk, 2018).

Pekerjaan mengajar di sekolah merupakan pekerjaan yang memerlukan keahlian khusus. Sebagai kegiatan yang berkaitan dengan pembinaan potensi anak yang sedang mengalami perkembangan, maka seorang guru harus benar-benar ahli atau profesional dalam tugasnya. Dengan kata lain jiwa dan semangat seorang guru yang mempunyai keahlian dan mengutamakan untuk mengabdi kepada nilai-nilai kemanusiaan melalui pembelajaran di sekolah. 
Dalam upaya menghasilkan calon pendidik yang profesional dalam menjalankan keahliannya dalam bidang pendidikan maka praktik pengalaman lapangan (PPL) sangat diwajibkan kepada mahasiswa. PPL merupakan salah satu kegiatan akademik yang bersifat intrakurikuler yang mencakup latihan mengajar dan tugas-tugas kependidikan lainnya secara terbimbing, terarah dan terpadu agar dapat memenuhi persyaratan pembentukan tenaga guru yang professional dalam kependidikannya.

Menurut Undang-Undang Nomor 14 Tahun 2005 tentang Guru dan Dosen yang terdapat dalam Jurnal Realita (Fanani, 2016) dikatakan bahwa, seorang guru bisa dikatakan kompeten apabila telah menguasai empat kompetensi dasar, yaitu kompetensi pedagogik, kompetensi kepribadian, kompetensi sosial dan kompetensi profesional. Seorang mahasiswa yang melaksanakan PPL di sekolah diharuskan untuk menguasai ke empat kompetensi dasar tersebut. seorang mahasiswa yang melaksanakan PPL di sekolah sudah di anggap sebagai seorang guru yang turut serta dalam pembelajaran di sekolah.

Sebelum melakukan PPL mahasiswa terlebih dahulu dibekali mengenai kependidikan melalui mata kuliah yang berkaitan dengan PPL yaitu mata kuliah Micro Teaching. Pada mata kuliah Micro Teaching tersebut mahasiswa akan diajarkan bagaimana menjadi seorang guru dan apa saja yang harus dikuasai sebelum mengikuti PPL dengan cara praktik langsung di depan kelas. Pada mata kuliah Micro Teaching juga mahasiswa akan dibekali keterampilan dasar mengajar, perancangan pembelajaran sebelum mahasiswa tersebut memasuki ruangan dan lain sebagainya.

Menurut Mulyasa (2016: 60) menyatakan keterampilan dasar mengajar merupakan suatu kompetensi profesional yang cukup kompleks sebagai salah satu integrasi dari berbagai kompetensi guru secara utuh dan menyeluruh. Keterampilan mengajar merupakan suatu kemampuan awal atau keterampilan awal yang harus dimiliki seorang guru sebelum memasuki atau memulai pembelajaran di dalam kelas.

Indikator keterampilan dasar mengajar adalah kedelapan keterampilan dasar mengajar yaitu keterampilan membuka dan menutup pelajaran, keterampilan bertanya, keterampilan memberi penguatan, keterampilan mengadakan variasi, keterampilan menjelaskan, keterampilan mengelola kelas, keterampilan membimbing diskusi kelompok kecil dan keterampilan mengajar kelompok kecil dan perorangan.

Dalam mengajar keterampilan dasar mengajar sangat penting dimiliki oleh seorang guru tidak terkecuali mahasiswa calon guru. Jika mahasiswa calon guru tidak mampu memahami dan mengaplikasikan keterampilan mengajar maka akan sulit bagi 
mahasiswa calon guru untuk melaksanakan PPL, karena hal yang paling utama bagi mahasiswa yang melaksanakan PPL adalah kemampuan dalam mengajar salah satunya adalah keterampilan mengajar (Rhamayanti, 2018).

PPL merupakan program atau mata kuliah yang diberikan kepada mahasiswa untuk memperoleh pengalaman sebagai seorang guru. Dalam program PPL tersebut akan terlihat mahasiswa yang secara kualitas telah mampu mengajar dan mahasiswa yang belum memiliki kemampuan yang baik. PPL ini merupakan ajang unjuk kerja atas ilmu yang telah di peroleh mahasiswa di bangku perkuliahan untuk dapat di aplikasikan. PPL di arahkan untuk membentuk kompetensi mengajar mahasiswa sehingga setelah lulus nanti akan memiliki kemampuan mengajar yang terampil dan produktif.

Keberhasilan PPL mahasiswa dipengaruhi oleh beberapa faktor. Diantara faktorfaktor tersebut antara lain adalah peran guru pamong dan dosen pembimbing. Guru pamong merupakan guru yang bertugas mendampingi mahasiswa yang melaksanakan praktikan selama melaksanakan PPL di sekolah latihan dan merupakan guru kelas terkait dengan bidang studi yang di tekuni oleh praktikan (Dasmo, 2014).

Seseorang yang memiliki pengetahuan dalam mengajar tentu akan berbeda dengan yang tidak memiliki pengetahuan terutama dalam hal keterampilan mengajar. Dalam hal ini guru perlu memiliki bekal ilmu yang harus dibawa maupun disiapkan sebelum turun kelapangan untuk mengajar. Yang paling utama dalam hal ini adalah ilmu ataupun pengetahuan dalam keterampilan dasar mengajar yang dapat digunakan sebagai modal dasar dalam mengajar kepada peserta didiknya agar mereka dapat menerima suatu pelajaran dengan baik.

Berdasarkan hasil wawancara peneliti bersama salah satu guru pamong di MAN 2 Padangsidimpuan Bapak Yurnalis, mengatakan bahwa keterampilan mengajar mahasiswa PPL sudah terlaksana namun perlu ditingkatkan dalam hal pelaksanaan keterampilan mengajar. Sehingga nantinya mahasiswa dapat menjadi seorang guru yang profesional. Adapun hasil wawancara peneliti bersama salah satu guru pamong di MAN 2 Padangsidimpuan ibu Nurhelila Siregar, mengatakan bahwa keterampilan mengajar mahasiswa PPL sudah terlaksana namun masih terdapat kekurangan dalam hal kegiatan mengajar. Berdasarkan latar belakang di atas, maka peneliti tertarik untuk melakukan penelitian dengan judul "Profil Keterampilan Mengajar Mahasiswa Praktik Pengalaman Lapangan IAIN Padangsidimpuan.” Tujuan penelitian ini adalah untuk mengetahui bagaimana profil keterampilan mengajar mahasiswa praktik pengalaman lapangan 
Fakultas Tarbiyah dan Ilmu Keguruan IAIN Padangsidimpuan di MAN 2 Padangsidimpuan.

\section{METODE PENELITIAN}

Pelaksanaan penelitian ini dilaksanakan di MAN 2 Padangsidimpuan) yang menjadi lokasi pelaksanaan PPL FTIK Institut Agama Islam Negeri Padangsidimpuan. Waktu penelitian ini dimulai dari Januari 2020 sampai Maret 2020. Jenis Penelitian ini termasuk penelitian kualitatif dengan tujuan mendapatkan pemahaman yang sifatnya umum terhadap kenyataan sosial dari perspektif partisipan. Pemahaman tersebut akan diperoleh setelah dilakukan analisis terhadap kenyataan yang menjadi fokus penelitian. Partisipan adalah orang-orang yang di ajak berwawancara, diobservasi, diminta memberikan data, pendapat, pemikiran dan persepsinya (Sukmadinata, 2017).

Metode penelitian ini adalah metode kualitatif dengan pendekatan deskriptif dengan cara mengumpulkan informasi tentang Keterampilan Mengajar Mahasiswa Praktik Pengalaman Lapangan Fakultas Tarbiyah dan Ilmu Keguruan IAIN Padangsidimpuan di MAN 2 Padangsidimpuan. Subjek dalam penelitian ini adalah seluruh guru pamong di MAN 2 Padangsidimpuan yang berjumlah 5 orang. Untuk mengumpulkan data yang di butuhkan dari lapangan penelitian digunakan instrumen pengumpulan data yaitu sebagai berikut: Pertama melalui Observasi. Oservasi sebagai salah satu teknik pengumpulan data (Rangkuti, 2016:143). Pada penelitian ini, peneliti mengumpulkan data dengan melakukan observasi terhadap mahasiswa selama melakukan PPL di MAN 2 Padangsidimpuan. Observasi dilakukan pada saat mahasiswa melakukan praktik mengajar di kelas. Kedua, Wawancara atau interview merupakan salah satu bentuk teknik pengumpulan data yang banyak digunakan dalam penelitian deskriptif kualitatif. Wawancara dilaksanakan secara lisan dalam pertemuan tatap muka secara individual (Sukmadinata, 2016). Wawancara yang dilaksanakan dalam penelitian ini adalah melaksanakan wawancara dengan guru pamong MAN 2 Padangsidimpuan). Wawancara merupakan alat re-cheking atau pembuktian terhadap informasi atau keterangan yang diperoleh sebelumnya. Ketiga, dokumentasi merupakan istilah dokumentasi berasal dari kata dokumen, yang dalam Bahasa Belanda disebut document dan dalam Bahasa Inggris disebut document. Dokumen berarti wahana informasi data 
yang terekam atau yang dimuat dalam wahana tersebut beserta maknanya yang digunakan untuk belajar, kesaksian, penelitian dan sejenisnya (Purwono, 2009).

\section{HASIL PENELITIAN DAN PEMBAHASAN}

Keterampilan Mengajar Mahasiswa Praktik Pengalaman Lapangan Fakultas Tarbiyah dan Ilmu Keguruan IAIN Padangsidimpuan di MAN 2 Padangsidimpuan sudah terlaksana dengan baik. Namun, masih perlu adanya peningkatan dari setiap komponen keterampilan mengajar, seperti keterampilan membuka dan menutup pelajaran, keterampilan menjelaskan, keterampilan bertanya, keterampilan mengadakan variasi, keterampilan memberikan penguatan, keterampilan mengelola kelas, keterampilan mengajar kelompok kecil dan perseorangan, dan keterampilan memimpin diskusi kelompok kecil. Agar setiap keterampilan mengajar dapat dikuasai dengan baik oleh setiap mahasiswa PPL sebagai calon guru yang profesional.

Berdasarkan analisis data yang diperoleh dari hasil penelitian, Persepsi Guru pamong Terhadap Keterampilan Mengajar Mahasiswa Praktik Pengalaman Lapangan Fakultas Tarbiyah dan Ilmu Keguruan IAIN Padangsidimpuan di MAN 2 Padangsidimpuan yaitu: Pertama, Keterampilan Membuka dan Menutup Pelajaran: dalam keterampilan membuka dan menutup pelajaran, seorang guru harus mampu menyiapkan mental anak sebelum memulai pembelajaran agar terpusat pada apa yang akan dipelajari. Sesuai yang ditemui di lapangan, keterampilan mahasiswa PPL dalam hal membuka dan menutup pelajaran, guru pamong memberikan persepsi sudah terlaksana. Namun pada dasarnya masih perlu ditingkatkan. Adapun yang perlu ditingkatkan oleh mahasiswa PPL dalam keterampilan membuka dan menutup pelajaran adalah: a. Memfokuskan perhatian dan membangkitkan minat siswa maksudnya dalam hal memfokuskan perhatian dan meningkatkan minat siswa, yang perlu ditingkatkan oleh mahasiswa PPL adalah: Memberikan arahan ataupun motivasi yang baik terhadap siswa, agar mereka dapat mengikuti proses pembelajaran tanpa adanya rasa keterpaksaan, merancang tempat pembelajaran diluar kelas. Karena hal tersebut dapat menarik perhatian siswa dalam mengikuti proses pembelajaran, memberikan arahan terhadap siswa dengan cara yang baik agar proses pembelajaran dapat berjalan dengan efektif dan efesien, gaya mengajar. Karena gaya mengajar guru akan mempengaruhi perhatian siswa saat berlangsungnya kegiatan proses pembelajaran dan penggunaan alat bantu atau media pengajaran. Karena dengan adanya penggunaan alat bantu dan media pengajaran, akan 
memungkinkan terjadinya kaitan antara hal yang telah diketahui dengan hal yang dipelajari oleh siswa serta akan menarik perhatian siswa. b. Menimbulkan motivasi yakni: dalam hal menimbulkan motivasi, yang perlu ditingkatkan oleh mahasiswa PPL adalah: Memberikan kehangatan dan menunjukkan sikap antusias terhadap siswa. Karena hendaknya mahasiswa PPL mampu bersikap antusias terhadap siswa saat berlangsungnya pembelajaran, memperhatikan minat siswa. Karena minat juga merupakan sumber motivasi yang dapat dilakukan oleh mahasiswa PPL dengan cara menyesuaikan topik pelajaran dengan minat siswa, memberikan masukan yang positif terhadap siswa. Karena apabila mahasiswa PPL memberikan masukan terhadap siswa dengan masukan yang positif maka hal tersebut dapat membangun kepercayaan dalam diri siswa, menciptakan suasana kelas yang kondusif. Karena kelas yang kondusif dapat menimbulkan motivasi terhadap siswa, memberikan penilaian terhadap hasil belajar siswa secara objektif sesuai dengan kemampua siswa. Yang mana nantinya hal tersebut dapat menjadi motivasi yang kuat untuk siswa, mengingatkan masalah pokok yang akan dibahas dalam pembelajaran. Karena hal tersebut dapat mempermudah siswa untuk mengetahui gambaran dari suatu pembelajaran yang akan disampaikan oleh mahasiswa PPL. c. Memberikan acuan dalam membuka pelajaran yakni dalam hal memberikan acuan dalam membuka pelajaran, yang perlu ditingkatkan oleh mahasiswa PPL adalah: Mengingatkan masalah pokok yang akan dibahas dalam pembelajaran. Karena hal tersebut dapat mempermudah siswa untuk mengetahui gambaran dari suatu pembelajaran yang akan disampaikan oleh mahasiswa PPL, mengemukakan tujuan dan batas-batas tugas yang harus dikerjakan oleh siswa. Karena hal tersebut akan membantu siswa untuk memperoleh gambaran yang jelas tentang ruang lingkup materi yang akan dipelajari dan tugas-tugas yang akan dikerjakan, mengemukakan indikator hasil belajar. Karena dalam membuka pelajaran, mahasiswa PPL akan mengingatkan masalah pokok yang akan di bahas dalam pembelajaran. d. Mengaitkan pelajaran yang telah dipelajari dengan topik baru yakni dalam hal mengaitkan pelajaran yang telah dipelajari dengan topik baru, yang perlu ditingkatkan adalah: Membandingkan contoh pelajaran yang sudah telah lewat dengan pembelajaran yang baru. Karena hal ini akan dapat menambah wawasan siswa terhadap pembelajaran yang disampaikan oleh mahasiswa PPL, mengaitkan pelajaran yang sudah lewat dengan pelajaran yang sedang dipelajari oleh siswa. Karena pada dasarnya siswa tidak terlepas dari kegiatan mengulas atau mengulang kembali pelajaran yang sudah dipelajari dengan apa yang sedang dipelajari, mengaitkan pelajaran yang telah disampaikan hari ini dengan 
yang sudah lewat agar siswa lebih memahami akan materi baru yang akan disampaikan. e. Meninjau kembali pelajaran yakni dalam hal meninjau kembali pelajaran, yang perlu ditingkatkan oleh mahasiswa PPL adalah: Merangkum kembali pembelajaran. Karena dalam kegiatan tersebut dapat dilakukan oleh mahasiswa PPL menjelang akhir pelajaran agar dapat diketahui apakah inti dari pembelajaran sudah dikuasai atau belum oleh setiap siswa, memberikan tugas berupa merangkum pembelajaran. Karena setelah selesai melaksanakan pembelajaran mahasiswa PPL dapat memberikan tugas kepada siswa berupa rangkuman yang akan di periksa pada minggu berikutnya, membuat kesimpulan secara lisan. Karena setelah selesai menjelaskan materi pembelajaran, mahasiswa PPL dapat menugaskan siswa agar membuat kesimpulan secara lisan tetang pembelajaran yang telah disampaikan demi memantapkan materi-materi pokok yang sudah dijelaskan. f. Mengevaluasi kembali pelajaran yakni dalam hal mengevalusi kembali pelajaran, yang perlu ditingkatkan oleh mahasiswa PPL adalah: Mengaplikasikan ide baru pada situasi lain. Karena hal tersebut dapat dilakukan untuk mengetahui apakah siswa sudah memeproleh wawasan yang utuh tentang suatu konsep yang diajarkan oleh mahasiswa PPL, Namun perlu ditingkatkan dalam hal mengevaluasi dalam bentuk non test. Karena mengevaluasi dalam bentuk non test dapat digunakan oleh mahasiswa PPL untuk mengevaluasi penampilan dan aspek-aspek belajar efektif dari siswa di madrasah ini, mengevaluasi dalam bentuk test Karena mahasiswa PPL harus berusaha untuk mengetahui apakah siswa di dalam kelas tersebut sudah memahami atau tidak pembelajaran yang telah disampaikan dengan cara memberikan tugas sesuai dengan materi yang telah di sampaikan. Kedua, Keterampilan Menjelaskan yaitu dalam keterampilan menjelaskan, seorang guru harus mampu menyampaikan informasi yang terencana dengan baik dan disajikan dengan urutan yang sesuai dengan tujuan pembelajaran. Sesuai yang ditemui di lapangan, keterampilan mahasiswa PPL dalam hal keterampilan menjelaskan, guru pamong memberikan persepsi sudah terlaksana. Namun pada dasarnya masih perlu ditingkatkan.

Adapun yang perlu ditingkatkan oleh mahasiswa PPL dalam keterampilan menjelaskan adalah: a. Penggunaan bahasa yang baik dan benar yaitu dalam penggunaan bahasa yang baik dan benar, yang perlu ditingkatkan oleh mahasiswa PPL adalah: Menghindari bahasa yang berbelit belit. Karena dalam hal ini mahasiswa harus mampu menngunakan bahasa yang mudah dimengerti oleh siswa dalam setiap proses pembelajaran, penggunaan tata bahasa. Karena tata bahasa merupakan suatu himpunan 
dari patokan-patokan dalam struktur bahasa yang semestinya dijadikan patokan bagi mahasiswa PPL dalam menjelaskan materi kepasa siswa, penggunaan kosakata bahasa Indonesia. Karena dalam penggunaan kosakata tersebut merupakan kumpulan kata yang merupakan bagian dari bahasa tertentu yang dapat digunakan oleh mahasiswa PPL untuk menyusun kalimat. b. Menggunakan bahasa yang jelas masudnya dalam penggunaan bahasa yang jelas, yang perlu ditingkatkan oleh mahasiswa PPL adalah: Penggunaan bahasa yang lugas dan santun. Karena dalam hal ini mahasiswa harus mampu dengan baik untuk menggunakan bahasa yang lugas dan santun yang bertujuan agar siswa lebih memahami materi pembelajaran yang disampaikan oleh mahasiswa PPL, menghindari pemborosan kata. Karena hal tersebut bertujuan agar siswa tidak bingung dalam memahami apa yang disampaikan oleh mahasiswa PPL, menggunakan bahasa yang mudah dipahami oleh siswa. Karena dalam hal ini mahasiswa PPL harus mampu dengan baik dalam menggunakannya. Karena hal tersebut bertujuan agar siswa yang mendengarkan penjelasan tersebut dapat memahami dengan baik apa yang disampaikan oleh mahasiswa PPL seperti: a. Menggunakan volume suara yang bervariasi maksudnya adalah bahwa dalam hal menggunakan volume suara yang bervariasi, yang perlu ditingkatkan oleh mahasiswa PPL adalah: memvariasikan intonasi suara dari tinggi ke rendah, dari besar ke kecil, dan dari nada sedih ke gembira. Karena hal tersebut bertujuan agar siswa dapat memahami materi yang sedang dijelaskan oleh mahasiswa PPL, menyesuaikan volume suara yang baik agar saat mahasiswa PPL menjelaskan materi pembelajaran bisa dipahami dengan baik oleh siswa. b. Menggunakan multi media untuk pokok bahasan tertentu dalam pembelajaran, maksudnya adalah dalam hal Menggunakan multi media untuk pokok bahasan tertentu dalam pembelajaran, yang perlu ditingkatkan oleh mahasiswa PPL adalah: Penggunaan media pembelajaran. Karena mahasiswa PPL belum sepenuhnya bisa menggunakan setiap media terhadap pokok bahasan tertentu, penggunaan media yang berbeda-beda. Karena di dalam pembelajaran Pendidikan Agama Islam (PAI) penggunaan multi media dalam pokok pembahasan pertama samapai yang terakhir akan berbeda pula media yang seharusnya di gunakan oleh mahasiswa PPL. Ketiga, Keterampilan Bertanya berupa adanya keterampilan bertanya, seorang guru harus mampu menciptakan pengetahuan agar dapat meningkatkan kemampuan berpikir terhadap siswa agar dapat menunjukkan interaksi yang dinamis dan multi arah antara guru dan siswa. Sesuai yang ditemui di lapangan, keterampilan mahasiswa PPL dalam keterampilan menjelaskan, guru pamong memberikan persepsi sudah terlaksana. Namun 
pada dasarnya masih perlu ditingkatkan. Adapun yang perlu ditingkatkan oleh mahasiswa PPL dalam keterampilan bertanya adalah: 1 . Pengungkapan pertanyaan secara jelas dan singkat. Pengungkapan pertanyaan secara jelas dan singkat, yang perlu ditingkatkan oleh mahasiswa PPL adalah: Cara mengungkapkan pertanyaan yang di ajukan oleh mahasiswa PPL terhadap siswa. Karena hal tersebut bertujuan agar mendapatkan respon yang baik dari setiap siswa, memberikan pertanyaan sesuai dengan materi yang diajarkan. Karena hal tersebut bertujuan untuk mempermudah siswa untuk menjawab setiap pertanyaan yang diberikan oleh mahasiswa PPL. Selanjutnya adanya pemberian acuan. Pemberian acuan, yang perlu ditingkatkan oleh mahasiswa PPL adalah: Memfokuskan topik atau materi yang akan dipertanyakan. Karena dalam pemberian acuan ini akan menjadikan pemahaman peserta didik terhadap materi yang akan ditanyakan terbatasi dan jelas dalam struktur kognitif peserta didik, menyampaikan ilustrasi. Karena daya tangkap dari setiap siswa itu pasti berbeda dan pemberian acuan ini akan lebih menambah penjelasan terhadap siswa di setiap pembelajaran yang dilaksanakan. Berikutnya, memusatkan jawaban kearah yang diminta, maksudnya adalah bahwa dalam memusatkan jawaban ke arah yang diminta, yang perlu ditingkatkan oleh mahasiswa PPL adalah: Memberikan tingkat pertanyaan. Karena dalam hal ini mahasiswa PPL harus mampu memberikan pertanyaan mulai dari hal yang lebih rendah agar siswa mudah memahami pertanyaan, memberikan stimulus atau rangsangan terhadap siswa. Karena hal tersebut bertujuan untuk merangsang kemampuan berfikir siswa agar dapat menjawab pertanyaan yang diberikan oleh mahasiswa PPL. Pada bagian selanjutnya, Pemindahan giliran menjawab berarti pemindahan giliran menjawab, yang harus ditingkatkan oleh mahasiswa PPL adalah: Memberi giliran menjawab. Karena sangat diharapakan agar seluruh siswa mendapat giliran dalam menjawab pertanyaan dari mahasiswa PPL meskipun tidak harus dalam satu waktu, melibatkan peserta didik untuk menjawab pertanyaan. Karena mahasiswa PPL tidak boleh hanya monoton kepada satu orang siswa saja untuk menjawab pertanyaan yang telah diberikan. Selain itu, adanya penyebaran pertanyaan yang harus ditingkatkan oleh mahasiswa PPL adalah: Memberikan pertanyaan. Karena dalam hal ini mahasiswa harus mampu memberikan pertanyaan yang berbeda dan melibatkan banyak siswa yang akan menjawab pertanyaan tersebut dengan jawaban yang berbeda, meberikan pertanyaan yang mudah dipahami. Karena dalam penyebaran pertanyaan, mahasiswa PPL diharapkan agar dapat memberikan pertanyaan yang berbeda tapi mudah dipahami oleh siswa. Langkah berikutnya adalah beri waktu untuk berpikir. 
Pemberian waktu berpikir, yang perlu ditingkatkan oleh mahasiswa PPL adalah: Mengatur lalu lintas bertanya yang diajukan oleh mahasiswa PPL terhadap siswa. Karena, hal tersebut bertujuan agar seluruh siswa dapat memahami dan dapat jawaban yang disampaikan oleh teman-temannya, memberikan penambahan waktu berfikir terhadap siswa. Karena dengan adanya penambahan waktu berfikir maka siswa yang belum mendapatkan jawaban di awal pertanyaan akan dapat memberikan jawabannya dengan baik. Langkah berikutnya adalah adanya pemberian tuntunan, yang perlu ditingkatkan oleh mahasiswa PPL adalah: Mengungkapkan kembali pertanyaan dengan cara yang lain yang lebih mudah dipahami dan sederhana. Karena tujuan dari mengungkapakan kembali pertanyaan dengan cara yang lain adalah agar siswa lebih memahami pertanyaan dari mahasiswa PPL, mengajukan pertanyaan lain yang lebih sederhana namun dapat menuntun siswa agar dapat menemukan jawabannya. Karena hal tersebut dapat mendorong siswa untuk lebih aktif dalam setiap pembelajarannya. Kemudia, adanya pengubahan tuntunan tingkat kognitif dalam mengubah pertanyaan, yang perlu ditingkatkan oleh mahasiswa PPL adalah: Tingkat pertanyaan yang diajukan. Karena mahasiswa PPL harus bisa mengajukan pertanyaan mulai dari yang sederhana menuju yang paling kompleks, mencari tahu apakah siswa sudah memahami pembelajaran yang telah diajarkan sebelumnya. Karena, hal tersebut bertujuan agar siswa lebih mudah untuk memahami pertanyaan dari mahasiswa PPL.

Keterampilan mengadakan variasi, seorang guru harus mampu mengatasi kebosanan siswa sehingga siswa mampu menunjukkan ketekunan, keantusiasan dan akan berperan serta secara aktif dalam mengikuti kegiatan pembelajaran. Sesuai yang ditemui di lapangan, keterampilan mahasiswa PPL dalam keterampilan mengadakan variasi, guru pamong memberikan persepsi sudah terlaksana. Namun pada dasarnya masih perlu ditingkatkan, seperti mengadakan variasi dalam gaya mengajar guru, yang harus ditingkatkan mahasiswa PPL adalah: Penekananan atau focusing. Karena untuk memfokuskan perhatian siswa, pada suatu aspek yang penting mahasiswa diharapkan mampu menggunakan penekanan secara verbal yang dikombinasikan dengan gerakan badan, kontak pandang antara mahasiswa dengan siswa. Karena hendaknya saat mahasiswa PPL berbicara ataupun berinteraksi dengan siswa sebaiknya mengarahkan pandangannya ke seluruh kelas dengan cara menatap mata peserta didik untuk dapat membentuk hubungan yang positif. Pentingnya mengadakan variasi dalam penggunaan media dan alat pembelajaran, yang harus ditingkatkan oleh mahasiswa PPL adalah: 
Menggunakan variasi media yang dapat dilihat. Karena penggunaan media tersebut digunakan sebagai alat dan bahan ajar khusus untuk komunikasi, mengadakan variasi media yang dapat di diraba, di manipulasi dan di gerakkan. Karena variasi media tersebut merupakan penggunaan media yang memberikan kesempatan kepada siswa untuk menyentuh dan memperagakan. Selain itu, harus mengadakan variasi pola interaksi dan kegiatan siswa, yang harus ditingkatkan oleh mahasiswa PPL adalah: Mengadakan pola antara guru dengan murid dan murid dengan guru. Karena hal ini merupakan pola yang harus ditingkatkan oleh mahasiswa PPL yang mana dalam hal ini guru berperan sebagai pemberi aksi atau penerima aksi dan hanya peserta didik yang bisa sebagai penerima aksi atau pemberi aksi yang dimana akan terjadi dialok antara peserta didik dengan guru, menggunakan pola guru dengan peserta didik dan peserta didik dengan peserta didik.

Selanjutnya mahasiswa harus tetap berusaha agar mampu mengubah variasi pola interaksi dan aktivitas demi keberhasilan siswa dalam mencapai tujuan pembelajaran. Di samping itu, sebagai calon guru harus memberikan penguatan maksudnya adalah sebagai calon guru harus mampu memberikan respon positif kepada peserta ataupun siswa yang telah melakukan suatu perbuatan baik. Sesuai yang ditemui di lapangan, keterampilan mahasiswa PPL dalam keterampilan memberikan penguatan, guru pamong memberikan persepsi sudah terlaksana. Namun pada dasarnya masih perlu ditingkatkan seperti: memberikan penguatan verbal dengan memberikan penguatan dengan cara memberikan dukungan. Karena dengan cara mahasiswa PPL memberikan dukungan terhadap siswa, maka siswa akan lebih mudah untuk tetap berfikir yang baik dalam setiap pembelajarannya, cara mahasiswa PPL memberikan penguatan dengan memberikan dukungan sehingga apabila siswa diberikan dukungan dalam pembelajarannya, maka siswa akan lebih merasa termotivasi dalam proses pembelajarannya.

Setelah itu, memberikan penguatan dengan mengekspresikan wajah ceria sehingga mahasiswa PPL harus mampu mengekspresikan wajahnya dengan cara tersenyum sebagai tanda kepuasan dari seorang guru terhadap respon dari siswanya, memberikan penguatan dengan anggukan kepala. Karena dalam hal ini mahasiswa harus bisa menerima respon dari siswa dengan cara memberikan anggukan kepala tanda setuju terhadap respon yang telah diberikan. Selanjutnya harus memberikan penguatan dengan cara melangkah mendekati siswa. Karena apabila mahasiswa PPL mampu dengan baik memberikan penguatan dengan melakukan cara tersebut maka siswa akan merasa lebih diperhatikan oleh gurunya, memberikan penguatan dengan cara berdiri disamping siswa. 
Karena apabila mahasiwa PPL mampu mendampingi siswa dalam setiap proses pembelajarannya, maka siswa akan merasa lebih termotivasi dalam mengikuti kegiatan pembelajarannya. Bukan itu saja, mahasiswa PPL adalah: Memberi penguatan dengan cara menepuk-nepuk bahu siswa. Karena dengan cara menepuk-nepuk bahu siswa, maka siswa akan merasa senang dalam mengikuti proses pembelajarannya, memberikan penguatan dengan cara menjabat tangan siswa. Karena hal tersebut dapat dilakukan oleh mahasiswa PPL untuk membuat siswa merasa lebih dihargai dengan keberhasilan yang telah ia peroleh dalam suatu kegiatan. Langkah-langkah yang harus disiapkan adalah seorang guru harus mampu menciptakan dan memelihara suasana belajar yang optimal. Sesuai yang ditemui di lapangan, keterampilan mahasiswa PPL dalam keterampilan mengelola kelas, guru pamong memberikan persepsi sudah terlaksana. Namun pada dasarnya masih perlu ditingkatkan.

Adapun yang perlu ditingkatkan oleh mahasiswa PPL dalam keterampilan menjelaskan adalah: memusatkan perhatian siswa dengan cara memberikan pertanyaan yang membuat siswa penasaran. Karena hal tersebut akan membuat siswa penasaran dan akan memunculkan rasa ingin tahu dalam diri siswa sehingga mereka akan memperhatikan guru dengan sendirinya, memberikan penguatan dengan cara bersuara lebih keras. Karena hal tersebut dapat dilakukan oleh mahasiswa PPL apabila suasana kelas dalam keadaan rIbut yang akan menjadikan suara guru tidak didengarkan oleh siwa. Berikutnya, memberikan teguran. karena mahasiswa PPL harus mampu bersikap tanggap kepada siswa yang berada di dalam kelas seperti, memberikan teguran dan akan memberikan sanksi kepada siswa yang suka bercerita dengan teman-temannya saat jam pelajaran berlangsung, memberikan reaksi terhadap suatu keadaan. Karena mahasiswa PPL diharapkan agar dapat dengan cepat memberikan reaksinya terhadap apa yang terjadi ataupun mendekati siswa yang membuat kekacuan saat berlangsungnya kegiatan proses belajar mengajar di dalam kelas. Memberi komentar. Karena dalam memberi komentar akan dapat menjadikan siswa lebih bersemangat dalam mengerjakan tugasnya apabila komentar itu diberikan dengan cara yang baik ataupun dengan cara yang lembut, memberi penjelasan. Karena dengan memberikan penjelasan akan menjadikan siswa yang belum memahami pembelajaran merasa diperhatikan dengan cara yang baik jika mahasiswa PPL mampu memberikan penjelasan dengan cara yang baik pula. Memberikan teguran secara tertulis. Karena mahasiswa PPL bisa menggunakan teguran tersebut di dalam buku siswa yang melakukan pelanggaran dalam proses pembelajaran, memberikan teguran dengan 
cara memberikan pendekatan terhadap siswa. Karena hal ini dapat dilakukan oleh mahasiswa PPL untuk memberikan teguran yang baik tanpa memperbesar masalah yang terjadi. Keterampilan mengajar kelompok kecil dan perseorangan, guru harus mampu mengajar siswa baik secara kelompok maupun perseorangan serta mampu menentukan strategi yang tepat untuk melakukannya agar tujuan pembelajaran dapat tercapai dengan baik. Sesuai yang ditemui di lapangan, keterampilan mahasiswa PPL dalam keterampilan mengajar kelompok kecil dan perseorangan, guru pamong memberikan persepsi sudah terlaksana. Namun pada dasarnya masih perlu ditingkatkan.

Adapun yang perlu ditingkatkan oleh mahasiswa PPL dalam keterampilan mengajar kelompok kecil dan perseorangan melalui mengadakan pendekatan secara pribadi, mengorganisasi, membimbing dan memudahkan pelajaran, merencanakan dan melaksanakan kegiatan belajar mengajar. Dalam keterampilan memimpin diskusi kelompok kecil seorang guru harus mampu melibatkan sekelompok orang dalam interaksi tatap muka yang informal dengan berbagai pengalaman ataupun informasi dan juga pemecahan masalah. Sehingga, memungkinkan siswa dapat menguasai suatu konsep atau dapat memecahkan suatu masalah. Sesuai yang ditemui di lapangan, keterampilan mahasiswa PPL dalam keterampilan memimpin diskusi kelompok kecil, guru pamong memberikan persepsi sudah terlaksana. Namun pada dasarnya masih perlu ditingkatkan.

Adapun yang perlu ditingkatkan oleh mahasiswa PPL dalam keterampilan memimpin diskusi kelompok kecil adalah: memperjelas urunan pendapat, menganalisis pandangan siswa, meningkatkan urunan pikiran siswa

\section{KESIMPULAN}

Berdasarkan hasil penelitian dan analisis data yang telah diuraikan, maka dapat diperoleh kesimpulan bahwa Keterampilan Mengajar Mahasiswa Praktik Pengalaman Lapangan Fakultas Tarbiyah dan Ilmu Keguruan IAIN Padangsidimpuan di MAN 2 Padangsidimpuan sudah terlaksana dengan baik, seperti keterampilan membuka dan menutup pelajaran, keterampilan menjelaskan, keterampilan bertanya, keterampilan mengadakan variasi, keterampilan memberikan penguatan, keterampilan mengelola kelas, keterampilan mengajar kelompok kecil dan perseorangan, dan keterampilan memimpin diskusi kelompok kecil. Namun delapan keterampilan mengajar tersebut masih perlu adanya peningkatan dari setiap komponen keterampilan mengajar. 


\section{REFERENSI}

Dasmo, (2014). Peran Guru Pamong dan Dosen Pembimbing Terhadap Keberhasilan Program Pengalaman Lapangan (PPL) Mahasiswa," Jurnal Formatif, Volume. 4 No. 1

E. Mulyasa, (2016). Menjadi Guru Profesional, Menciptakan Pembelajaran Kreatif dan Menyenangkan. Bandung: Remaja Rosda Karya

Hasratuddin, (2015). Mengapa Harus Belajar Matematik? Medan: Perdana Publishing

Insan Kamil dkk (2018), "Persepsi Guru Pamong Terhadap Kemampuan Mengajar Mahasiswa Studi Kasus: SMKN 1 Tilatang Kamang dan SMKN 5 Padang," Jurnal Cived Jurusan Teknik Sipil, volume 5, No. 1, Maret 2018

Moh. Zainal Fanani, (2016) "Persepsi Guru Pamong Terhadap Pelaksanaan Praktik Pengalaman Lapangan (PPL) Mahasiswa," Jurnal Realita, Volume 14, No. 2 Juli 2016.

Nana Syaodih Sukmadinata, (2017) Metode Penelitian Pendidikan, Bandung: PT Remaja Rosdakarya

Nur Asia, (2019). Penerapan Keterampilan dasar Mengajar Guru di SMP Muhammadiyah Soni Dampal Selatan. Scolae: Journal of Paedagogy. Vol. 1 No. 1, 2019. hlm. 253261

Purwono, (2009) Konsep dan Definisi Dokumentasi, Jakarta: Universitas Terbuka

Rangkuti, A.N. \& Jusrina, (2017). Profesionalisme Guru Matematika MTs Muhammadiyah 22 Padangsidimpuan. Math Educa Journal, 1 (2) (2017): hlm. 117128

Yuni Rhamayanti, (2018). Pentingnya Keterampilan Dasar Mengajar Bagi Mahasiswa Praktek Pengalaman Lapangan (PPL) Prodi Matematika," Jurnal Penelitian dan Pembelajaran MIPA, Volume 3, No. 1 Tahun 2018 